\title{
Faktor - Faktor Yang Mempengaruhi Pendapatan Tenaga Kerja Perempuan Di Sektor Informal (Studi Kasus Pedagang Pasar Sanggeng Manokwari)
}

\author{
Framintolia Kaiway ${ }^{1}$, Siti Aisah Bauw ${ }^{2}$, Marcus R. Maspaitella ${ }^{3}$ \\ ${ }^{1}$ Alumni Jurusan Ekonomi Pembangunan, Universitas Papua \\ ${ }^{2,3}$ Dosen Jurusan Ekonomi Pembangunan, Universitas Papua
}

Received: Desember 2019; Accepted: Januari 2020; Published: Maret 2020

\begin{abstract}
Abstrak
Perempuan berperan sebagai istri bahkan ibu bagi anak-anak dalam rumah tangga dengan menjalankan tugas domestik di dalam rumah untuk mengurus dan melayani suami serta anggota keluarga. Ketika perempuan memiliki banyak kebutuhan tanggungan di dalam keluarga perempuan mengambil peran ganda untuk terserap di dunia kerja pada sektor informal sebagai pedagang dengan berdagang di pasar guna untuk menghasilkan pendapatan agar bisa memenuhi kebutuhan hidup keluarga. Penelitian ini bertujuan untuk menganalisis faktor faktor umur, jam kerja, tigkat pedidikan, dan jumlah tanggungan terhadap pendapatan pedagang perempuan di Pasar Sanggeng Manokwari dengan menggunakan alat analisis regresi linear berganda. Hasil regresi menunjukan adanya pengaruh Umur dan Jam kerja secara signifikan terhadap pendapatan pedagang perempuan, sementara tingkat pendidikan dan jumlah tanggungan tidak menunjukan pengaruh yang signifikan terhadap pendapatan pedagang perempuan di Pasar Sanggeng Manokwari.
\end{abstract}

Kata kunci: umur, jam kerja,tingkat pendidikan, jumlah tanggungan, pendapatan

\begin{abstract}
Women act as wives and even mothers for children in the household by carrying out domestic tasks at home to take care of and serve their husbands and family members. When women have many dependent needs in the family, women take on a dual role to be absorbed in the world of work in the informal sector as traders by trading in the market in order to generate income in order to meet the needs of family life. This study aims to analyze the factors of age, working hours, education level, and the number of dependents on the income of female traders in Sanggeng Manokwari Market by using multiple linear regression analysis tools. The regression results show that there is a significant effect of age and working hours on the income of female traders, while the level of education and number of dependents does not show a significant effect on the income of female traders in the Sanggeng Manokwari Market.
\end{abstract}

Keywords: age, working hours, education level, number of dependents, income

How to Cite: Bauw, dkk. (2020). Faktor - Faktor Yang Mempengaruhi Pendapatan Tenaga Kerja Perempuan Di Sektor Informal (Studi Kasus Pedagang Di Pasar Sanggeng Manokwari). JFRES: Journal of Fiscal and Regional Economy Studies, 3(2), 27 - 36

\footnotetext{
Corresponding author:

E-mail: aisahbauwfebunipa@gmail.com
} 


\section{PENDAHULUAN}

Dalam rumah tangga perempuan atau istri memberikan semua pelayanan untuk anak-anak, suami dan anggota-anggota keluarga lainnya sepanjang hidupnya, perempuan juga tersembunyi dalam rumah tangga dan berkutat dengan 3 M yaitu masak (memasak), macak (bersolek), manak (melahirkan anak), Bhasin (1996). Rendahnya sumber daya kaum perempuan secara umum disebabkan oleh ketidak adilan gender, sistem sosial budaya tradisional yang lebih berpihak kepada laki-laki, serta adanya penafsiran terhadap ajaran agama yang lebih menguntungkan dan menempatkan kaum laki-laki setingkat lebih tinggi dari kaum perempuan yang menjadikanya termarginal dan tereksploitasi oleh kaum laki-laki (Rabain, 2002).

Perempuan yang berstatus sebagai ibu rumah tangga pada dasarnya bukan tidak terserap dalam dunia kerja tetapi karena pilihan untuk mengurus rumah tangga. Seiring dengan kemajuan jaman maka berkembangnya informasi dan tingkat kemampuan intelektual manusia membuat peran perempuan dalam kehidupannya terus berubah untuk menjawab tantangan jaman tak terkecuali mengenai peran perempuan dalam meningkatkan kesejahteraan keluarga.

Perempuan berusaha memperoleh pekerjaan untuk mendapatkan penghasilan disebabkan karena beberapa hal, antara lain adanya kemauan perempuan untuk bermandiri dalam bidang ekonomi, yaitu berusaha membiayai kebutuhan hidupnya dan mungkin juga kebutuhan hidup dari orang-orang yang menjadi tanggungannya dengan penghasilan sendiri. Kemudian terdapat pula adanya kebutuhan untuk menambah penghasilan keluarga serta alasan lainnya ialah makin meluasnya kesempatan kerja yang menyerap tenaga kerja perempuan, juga menjadi salah satu faktor pendorong perempuan untuk bekerja (Sonny, 2009).

Perempuan memilih untuk bekerja karena penghasilan yang diperoleh suami atau anggota keluarga laki-laki lain dalam rumah tangga tidak mencukupi kebutuhan keluarga sehari-hari. Bekerja di luar rumah juga dilakukan sebagai suatu strategi kaum perempuan dengan tujuan ganda yakni memperoleh penghasilan sambil memastikan diri bahwa pekerjaan-pekerjaan domestik tetap terlaksana dengan baik. Meskipun demikian, pekerjaan yang mereka lakukan masih sering dipandang sebagai pengisi waktu luang atau pekerjaan sampingan yang tujuanya untuk menambah pendapatan keluarga.

Peran ganda perempuan atau ibu rumah tangga menurut Kartini (1994) adalah peranan perempuan dalam dua bentuk yaitu perempuan yang berperan di bidang domestik dan perempuan karier. Yang dimaksud dengan bidang domestik adalah perempuan yang hanya bekerja di rumah saja sebagai istri dan hanya mengurus rumah tangga. Sedangkan yang dimaksud dengan perempuan karier adalah apabila mereka bekerja di luar, maupun bekerja secara profesional karena ilmu yang didapat atau karena ketrampilannya.

Sejak terbentuknya kesempatan kerja bagi perempuan di luar perannya sebagai ibu rumah tangga, perempuan menyesuaikan perannya sebagai ibu rumah tangga dan sebagai pencari nafkah. Partisipasi kerja ini tidak saja menyebabkan penambahan penghasilan rumah tangga, tetapi dengan meningkatkan peran perempuan dalam mengambil keputusan. Perempuan yang bekerja merupakan salah satu bentuk mobilitas sosial perempuan. Mobilitas yang dilakukan berdasarkan kemampuan dan potensi baik secara pendidikan maupun kemandirian belum mencapai presentasi yang sama dengan laki-laki.

Motivasi perempuan untuk bekerja diantaranya suami tidak bekerja, pendapatan rumah tangga rendah sedangkan jumlah tanggungan keluarga cukup tinggi, mengisi waktu luang, ingin mencari uang sendiri dan ingin mencari pengalaman (Asyiek,dkk dalam Artini dan Handayani 2009). Lebih lanjut Artini dan Handayani (2009) mengatakan bahwa umumnya perempuan termotivasi untuk bekerja adalah untuk membantu menghidupi keluarga dan umumnya bekerja di sektor informal. Hal ini dilakukan agar dapat membagi waktu antara pekerjaan dan keluarga. Selain itu motivasi kerja juga mempunyai pengaruh yang kuat terhadap perempuan yang sudah menyadari dan mengetahui akan hak dan tanggung jawabnya sebagai mitra sejajar pria, dimana perempuan itu akan mencari kerja dengan mengandalkan kemampuan yang dimilikinya untuk mendapat penghasilan karena merasa mempunyai kesempatan dan kemampuan untuk bekerja.

Hal di atas juga berlaku di suatu daerah salah satunya di Kabupaten Manokwari yang dibuktikan melalui jumlah angkatan kerja di Kabupaten Manokwari menurut jenis kelamin 
dan jenis pekerjaan utama yang menunjukan adanya partisipasi perempuan yang bekerja dan masuk dalam angkatan tenaga kerja perempuan

Tabel 1. Jumlah Penduduk Umur 15 Tahun Ke Atas Yang Bekerja Selama Seminggu Pada Pekerjaan Utama Menurut Jenis Kelamin, Tahun 2015

\begin{tabular}{lccc}
\hline \multicolumn{1}{c}{ Status Pekerjaan Utama } & Laki-laki & Perempuan & Jumlah \\
\hline Berusaha sendiri & 5.548 & 3.735 & 9.283 \\
\hline Berusaha dibantu buruh tidak tetap/buruh tak dibayar & 8.064 & 4.106 & 12.170 \\
\hline Berusaha dibantu buruh tetap/buruh dibayar & 1.864 & 565 & 2.429 \\
\hline Buruh/Karyawan/Pegawai & 21.404 & 8.398 & 29.802 \\
\hline Pekerja bebas & 3.409 & 574 & 3.983 \\
\hline Pekerja keluarga/tak dibayar & 3.185 & 7.853 & 11.020 \\
\hline \multicolumn{1}{c}{ Jumlah/Total } & $\mathbf{4 3 . 4 7 4}$ & $\mathbf{2 5 . 2 1 3}$ & $\mathbf{6 8 . 6 8 7}$ \\
\hline
\end{tabular}

Sumber data: BPS Manokwari, 2018

Tabel 1 menunjukkan bahwa jumlah penduduk yang bekerja sebagai Buruh/Karyawan/Pegawai adalah yang terbanyak pada status pekerjaan (Buruh/ Karyawan/ Pegawai/ Pekerja bebas) laki-laki sebanyak 21.404 orang, perempuan sebanyak 8.398 orang, jumlah untuk status pekerjaan ini berjumlah 29.802 orang, dan yang paling sedikit pada status pekerjaan Berusaha dibantu buruh tetap/buruh dibayar sebanyak 2.429 orang yang terdiri dari laki-laki sebanyak 1.864 orang, perempuan sebanyak 565 orang.

Keterlibatan perempuan di pasar kerja bermaksud membantu menjawab persoalan ekonomi keluarga maka perempuan bekerja di sektor informal dengan berdagang atau berjualan usaha kecil yang tidak membutuhkan biaya operasional yang besar. Pekerja sektor informal adalah tenaga kerja yang bekerja dalam hubungan kerja sektor informal dengan menerima upah dan atau imbalan (Undangundang ketenagakerjaan, 2003). Selain itu Pudjianto dan Mukhlis (2006) menyatakan alasan lain yang menyebabkan perempuan memilih bekerja di sektor informal adalah tidak tersedianya lapangan pekerjaan yang sesuai dengan tingkat pendidikan mereka. Salah satu kegiatan di sektor informal yang banyak dilakukan adalah usaha dagang. Salah satu kawasan yang umum didatangi para pedagang perempuan pada sektor informal adalah Pasar Sanggeng yang terletak di Kelurahan Sanggeng Distrik Manokwari Barat.

Pedagang perempuan yang berdagang di Pasar Sanggeng sebagian besar adalah ibu rumah tangga yang kesehariannya mengurus rumah tangga kemudian meluangkan sebagian waktunya untuk berdagang sejak pukul 07.00 WIT hingga pukul 18.00 WIT dengan tujuan untuk menambah pendapatan yang nantinya di Kabupaten Manokwari yang cukup besar jumlahnya yang di tunjukan pada tabel 1 . digunakan untuk memenuhi kebutuhan keluarganya. Umumnya jumlah pedagang di Pasar Sanggeng didominasi oleh Pedagang Asli Papua dengan latar belakang petani pedagang atau pedagang pengumpul yaitu mereka yang dagangannya sebagian dari hasil kebun dimana hasil kebunnya didatangkan langsung dari kampung-kampung pemasok yang terletak di wilayah Pantai Utara, dan Anggi. Sisanya ada pedagang etnis Non Papua sebagai pedagang kios, gerai pedagang pakaian, kelontong, sembako, dan berbagai jenis dagangan lainnya.

Tabel 2. Pedagang Perempuan di Pasar Sanggeng Manokwari Tahun 2018

\begin{tabular}{lcc}
\multicolumn{1}{c}{ Jenis Usaha } & Jumlah & Keterangan \\
\hline Warung makan & 20 & Tetap \\
\hline Pakaian & 37 & Tetap \\
\hline Sayur dan hasil kebun & 300 & Tidak tetap \\
\hline $\begin{array}{l}\text { Aksesoris, sepatu, } \\
\text { sandal dan kosmetik }\end{array}$ & 63 & Tetap \\
\hline Pinang & 80 & Tidak tetap \\
\hline \multicolumn{1}{c}{ Total } & $\mathbf{5 0 0}$ & \\
\hline
\end{tabular}

Sumber: Dinas Perindagkop Kab. Manokwari, 2018

Tabel 2 menunjukan Jumlah Pedagang Perempuan menurut Jenis Usaha di Pasar Sanggeng terbanyak adalah pada Jenis jualan sayur dan hasil kebun yaitu sebanyak 300 orang dan yang paling pada jenis usaha warung makan jumlah pedagang perempuannya sebanyak 20 orang, dari keseluruhan pedagang perempuan yang ada di Pasar Sanggeng sebanyak 500 orang.

Dewi (2012) dalam penelitiannya tentang pendapatan tenaga kerja perempuan menunjukkan faktor tingkat pendidikan dan jenis pekerjaan berpengaruh nyata terhadap pendapatan perempuan. Penelitian sebelumnya juga dilakukan oleh Sari (2010) menemukan 
bahwa Umur, Status Perkawinan dan Pendidikan berpengaruh terhadap pendapatan pekerja perempuan sektor informal. Meningkatnya jumlah tanggungan yang dimiliki, maka meningkat pula beban tanggungan keluarga tersebut. Simanjuntak (2001), jumlah tanggungan yang tinggi pada suatu rumah tangga tanpa diikuti dengan peningkatan dari segi ekonomi akan mengharuskan anggota keluarga selain kepala keluarga untuk mencari nafkah.

Tenaga kerja adalah semua orang yang bersedia untuk sanggup bekerja, baik bekerja untuk diri sendiri ataupun anggota keluarga yang tidak menerima bayaran, dalam arti mereka yang mengganggur. Tenaga kerja mencakup penduduk yang sudah sedang bekerja, sedang mencari pekerjaan dan yang melakukan pekerjaan lain seperti sekolah dan mengurus rumah tangga (Sumarsono, 2003). Berdasarkan UU No. 13 tahun 2003, tenaga kerja adalah setiap orang yang mampu melakukan pekerjaan guna menghasilkan barang atau jasa baik untuk memenuhi kebutuhan sendiri maupun untuk masyarakat (Geminastiti, 2013). Tiap negara menentukan batas umur minimum dan maksimum yang berbeda untuk mendefinisikan tenaga kerja atau penduduk dalam umur kerja, sebab situasi tenaga kerja setiap negara berbeda. Batas umur minimum pada negara berkembang lebih rendah dari negara-negara maju sebab pada negara berkembang tingkat kesejahteraanya masih rendah. Anak-anak pada umur 10 tahun sampai 16 tahun yang seharusnya berada di sekolah terpaksa harus mencari kerja untuk memenuhi kebutuhan sosialnya (Sumarsono, 2003). Tenaga kerja wanita mencakup wanita yang tergolong bekerja, mencari kerja dan melakukan kegiatan seperti bersekolah dan mengurus rumah tangga Mulyadi (2002). Muriati (2006), tenaga kerja wanita merupakan tiap-tiap wanita yang melakukan pekerjaan di dalam maupun di luar hubungan kerja guna menghasilkan barang atau jasa, untuk memenuhi kebutuhan masyarakat.

Keterlibatan perempuan dalam mencari nafkah di sektor informal dapat berupa membuka usaha sendiri, maupun menjadi pekerja dalam sektor biasa, perdagangan, maupun industri. Terlebih dalam sistem sosial yang diterapkan dalam masyarakat dapat memberi peran yang sama antar laki-laki dan perempuan dalam bekerja (Hardyastuti dkk,1991). Sektor informal dirincikan oleh sektor ekonomi marginal dengan kondisi nyata kegiatan sejumlah tenaga kerja yang umumnya kurang berpendidikan dan hanya mempunyai ketrampilan (Muzakar, 2001). Berdasarkan kamus besar bahasa indonesia sektor informal adalah lingkungan usaha tidak resmi, lapangan pekerjaan yang diciptakan dan di usahakan sendiri oleh pencari kerja.

Ciri-ciri usaha yang tergolong dalam sektor informal adalah:

1. Kegiatan usaha pada umumnya sederhana, tidak tergantung pada kerjasama banyak orang dan sistem pembagian kerja yang tidak begitu ketat. Dengan demikan, dapat dilakukan oleh perorangan atau keluarga, atau usaha bersama antara beberapa orang atas kepercayaan tanpa perjanjian tertulis.

2. Skala usaha relatif kecil, modal usaha, modal kerja, dan omset penjualan pada umumnya kecil serta dapat dilakukan secara bertahap.

3. Usaha sektor informal umumnya tidak mempunyai ijin usaha seperti halnya dalam bentuk Firma atau Perseroan Terbatas (PT).

4. Untuk bekerja di sektor informal lebih mudah daripada di perusahaan formal. Seseorang dapat memulai dan melakukan sendiri usaha di sektor informal asal ada keinginan dan kesediaan untuk bekerja. Seseorang relatif lebih mudah bekerja dengan orang lain di sektor informal, misalnya karena persahabatan atau hubungan keluarga, walaupun keikut sertaan seseorang tersebut mungkin tidak menambah hasil keseluruhan.

5. Tingkat penghasilan di sektor informal umumnya rendah walaupun tingkat keuntungan kadang-kadang cukup tinggi, akan tetapi karena omset relatif kecil, keuntungan absolut umumnya menjadi kecil.

6. Keterkaitan sektor informal dengan usahausaha lain sangat kecil. Kebanyakan usahausaha sektor informal berfungsi sebagai produsen atau penyalur kecil yang langsung melayani konsumen atau pemakai. Pendeknya jalur tersebut justru membuat resiko usaha menjadi relatif lebih besar dan sangat terpengaruh pada perubahanperubahan yang terjadi pada konsumen.

7. Usaha sektor informal sangat beraneka ragam seperti pedagang kaki lima, pedagang kecil, tukang loak, buruh bangunan, serta usahausaha rumah tangga seperti pembuat tempe, pembuat kue, pembuat es keliling, penjahit. 
Faktor- faktor yang Mempengaruhi Perempuan Bekerja

1. Pendapatan Suami, dalam rumah tangga telah ada pembagian tugas antara suami dan istri. Suami dalam hal ini adalah kepala keluarga yang menjadi penanggung jawab atas kondisi perekonomian keluarga. Sedangkan istri bukan menjadi penanggung jawab utama sehingga istri tidak terlalu dituntut untuk bekerja di luar rumah. Penerimaan yang diperoleh dari pendapatan suami digunakan oleh istri dalam menentukan tingkat partisipasi istri untuk bekerja. Sehingga apabila suami dianggap telah cukup, maka kebanyakan istri hanya bekerja di rumah saja (Hardyastuti dkk,1991).

2. Tingkat Pendidikan Perempuan, semakin tinggi tingkat pendidikan seseorang semakin banyak waktu yang disediakan untuk bekerja. Terutama bagi para perempuan, dengan semakin tinggi pendidikan, kecendurungan untuk bekerja semakin besar, dan TPK semakin besar (Sumarsono, 2003). Semakin tinggi seorang perempuan menempuh pendidikan, semakin banyak ilmu yang diperoleh, dan semakin sering pula terjadi interaksi dengan pihak luar. Hal itu merupakan sebuah pengalaman sekaligus peluang yang dibutuhkan dalam dunia kerja.

3. Upah Tenaga Kerja Perempuan, konsep dan definisi yang digunakan dalam susenas menunjukan bahwa hanya kelompok tenaga kerja yang berstatus sebagai buruh atau pekerja saja yang mendapat gaji atau pendapatan. Pendapatan juga sangat berpengaruh terhadap jumlah jam kerja perempuan, upah merupakan variabel yang pengaruhnya terhadap jam kerja dapat berubah sewaktu-waktu, dimana apabila seseorang akan cenderung menambah jam kerjanya pada saat ia memiliki upah yang tinggi, namun apabila suatu saat nanti ia telah merasa bahwa upah yang telah ia terima sudah cukup maka ia akan cenderung mengurangi jumlah jam kerjanya (Thasya dan Muhammad, 2017). Suhartini (2010), mengemukakan bahwa faktor ekonomi umumnya mempengaruhi seorang perempuan bekerja karena dengan mendapatkan penghasilan maka perempuan dapat memenuhi kebutuhan sehari-hari. Semakin tinggi tingkat upah dalam masyarakat, semakin tinggi anggota keluarga termasuk perempuan yang tertarik masuk pasar kerja, atau dengan kata lain semakin tinggi Tingkat Partisipasi Kerja (TPK) (Sumarsono 2003).

4. Tingkat Produktivitas Kerja, produktivitas merupakan perbandingan antara hasil yang dicapai (keluaran) dengan keseluruhan sumber daya (masukan) yang digunakan dalam satuan waktu. Produktivitas akan mempengaruhi motivasi dari tiap-tiap individu. Produktivitas sangat berkaitan dengan tingkat pendidikan dan keterampilan yang dimiliki, dimana seseorang yang memiliki keterampilan dan tingkat pendidikan tinggi maka produktivitasnya juga tinggi, dan hal ini akan mempengaruhi kesediaanya untuk masuk dalam pasar tenaga kerja (Simanjuntak, 1998). Bagi perempuan yang memiliki keterampilan dan tingkat pendidikan yang tinggi, produktivitas kerjanya juga tinggi, sehingga akan memutuskan untuk bekerja daripada hanya diam di rumah. Hal ini juga dikarenakan adanya motivasi dalam diri perempuan untuk mengaktualisasikan dirinya dalam pasar tenaga kerja.

Pendapatan adalah seluruh penerimaan baik berupa uang maupun berupa barang yang berasal dari pihak lain maupun hasil industri yang dinilai atas dasar sejumlah uang dari harta yang berlaku saat itu. Pendapatan merupakan sumber penghasilan seseorang untuk memenuhi kebutuhan sehari-hari dan sangat penting artinya bagi kelangsungan hidup dan penghidupan seseorang secara langsung maupun tidak langsung (Suroto, 2000). Ada 3 kategori pendapatan yaitu:

1. Pendapatan berupa uang yaitu segala penghasilan berupa uang yang sifatnya reguler dan yang diterima biasanya sebagai balas jasa atau kontra prestasi.

2. Pendapatan berupa barang yaitu segala pendapatan yang sifatnya reguler dan biasa, akan tetapi selalu berbentuk balas jasa dan diterima dalam bentuk barang dan jasa.

3. Pendapatan yang bukan merupakan pendapatan adalah segala penerimaan yang bersifat transfer redistributif dan biasanya membuat perubahan dalam keuangan rumah tangga (Sunuharjo, 2009).

Berdasarkan uraian tersebut disimpulkan bahwa jumlah tanggungan berpengaruh positif terhadap pendapatan keluarga. Dengan demikian 
penelitian ini bertujuan untuk mengetahui apakah variabel umur, jam kerja, tingkat pedidikan dan jumlah anak berpengaruh positif dan signifikan terhadap pendapatan keluarga pedagang perempuan di Pasar Sanggeng Manokwari.

\section{METODE PENELITIAN}

Penelitian ini dilakukan di Pasar Sanggeng Kabupaten Manokwari. Lokasi ini sengaja dipilih karena memiliki jumlah pedagang perempuan yang cukup banyak. Penelitian ini menggunakan data primer dan data sekunder. Menurut Teguh (2015), data primer merupakan jenis data yang diperoleh dan digali dari sumber utamanya, baik berupa data kualitatif maupun data kuantitatif. Dalam penelitian ini, data primer diperoleh dari hasil wawancara yang dipandu menggunakan kuisioner. Data primer langsung diperoleh dari lapangan melalui wawancara dan kuisioner pada pedagang perempuan yang berdagang di lokasi penelitian yaitu di Pasar Sanggeng Kabupaten Manokwari Sedangkan data sekunder adalah jenis data yang diperoleh dan digali melalui hasil pengelolaan pihak kedua dari hasil penelitian lapangannya, baik berupa data kualitatif maupun kuantitatif. Data sekunder dalam penelitian ini diperoleh dari Dinas PERINDAGKOP dan UMKM Kabupaten Manokwari, dan studi pustaka lainnya yang mendukung penelitian ini.

Metode pengumpulan data dalam penelitian ini yaitu; Observasi, Observasi Merupakan metode pengumpulan data yang dilakukan dengan cara mengamati dan mencatat secara sistematik gejala-gejala yang diselidiki. Wawancara, Wawancara merupakan salah satu teknik pengumpulan data yang sering digunakan. Pelaksanaannya dapat dilakukan secara langsung berhadapan dengan yang diwawancarai, tetapi dapat juga secara tidak langsung seperti memberikan daftar pertanyaan untuk dapat dijawab pada kesempatan lain. Kuisioner, Kuisioner merupakan teknik pengumpulan data yang dilakukan dengan cara memberi seperangkat pertanyaan atau pernyataan tertulis kepada responden untuk dijawabnya Sugioyo (2015). Study Pustaka, Merupakan teknik pengumpulan data dan informasi dengan melakukan kegiatan kepustakaan melalui bukubuku, jurnal, dan sebagainya yang relevan dengan penelitian ini.

Metode analisis yang digunakan untuk menggambarkan hubungan antara variabel terikat dengan variabel bebasnya adalah dengan menggunakan model regresi berganda (multiple regression), dengan model persamaan sebagai berikut:

$$
Y=\alpha+\beta_{1} X_{1}+\beta_{2} X_{2}+\beta_{3} X_{3}+\beta_{4} X_{4}+e
$$

Keterangan:

$$
\begin{array}{ll}
\mathrm{Y} & =\text { Pendapatan Pedagang Perempuan } \\
\mathrm{X}_{1} & =\text { Umur } \\
\mathrm{X}_{2} & =\text { Jam Kerja } \\
\mathrm{X}_{3} & =\text { Tingkat Pendidikan } \\
\mathrm{X}_{4} & =\text { Jumlah Tanggungan } \\
\boldsymbol{\beta}_{1,2,3,4} & =\text { Koefisien Regresi } \\
\mathrm{e} & =\text { Standar Eror }
\end{array}
$$

\section{HASIL DAN PEMBAHASAN}

\section{Identitas Responden}

Identitas responden merupakan data pribadi yang dikumpulkan dari 83 responden pedagang perempuan dalam penelitian ini dengan tujuan untuk mengetahui faktor-faktor yang mempengaruhi pendapatan pedagang perempuan di Pasar Sanggeng.

\section{Distribusi Umur Responden Pedagang Perempuan}

Tabel 3. Distribusi Umur Responden Pedagang Perempuan

\begin{tabular}{cccrr}
\hline \multirow{2}{*}{ Umur } & \multicolumn{2}{c}{ Sektor Sekunder } & \multicolumn{2}{c}{ Sektor Primer } \\
\cline { 2 - 5 } & Orang & $\mathbf{\%}$ & Orang & \multicolumn{1}{c}{} \\
\hline $25-30$ & 10 & 20,41 & 8 & 23,53 \\
\hline $31-40$ & 24 & 48,98 & 17 & 50,00 \\
\hline $41-50$ & 12 & 24,49 & 6 & 17,65 \\
\hline$>50$ & 3 & 6,12 & 3 & 8,82 \\
\hline Total & 49 & 100 & 34 & 100 \\
\hline \multicolumn{7}{r}{ Total Responden } \\
\hline
\end{tabular}

Sumber: data primer diolah, 2019

Umur merupakan variabel yang berpengaruh terhadap pendapatan. Umur dapat dijadikan sebagai tolak ukur dalam melihat aktivitas seseorang dalam bekerja, dimana kondisi umur yang masih produktif maka kemungkinan besar seseorang dapat bekerja dengan baik dan maksimal, begitu pula sebaliknya jika seseorang berada pada umur non produktif kemungkinan tidak dapat bekerja dengan maksimal (Hasyim, 2006).

Dari Tabel 3 diketahui distribusi umur responden pedagang perempuan berdasarkan jenis usaha yang dikelompokan menjadi dua sektor yaitu sektor sekunder yang meliputi jenis usaha warung makan, pakaian, sepatu dan pinang 
responden dengan usia 25-30 tahun berjumlah 16 orang atau 20,41\% , usia antara 31-40 tahun berjumlah 24 orang atau 48,98\%, usia antara 4150 tahun berjumlah 12 orang atau $24,49 \%$, dan usia > 50 tahun berjumlah 3 orang atau $6,12 \%$. Kemudian sektor primer yang meliputi jenis usaha sayur, dan hasil kebun responden dengan usia 25-30 tahun berjumlah 8 orang atau 23,53\%, usia antara 31-40 tahun berjumlah 17 orang atau $50 \%$, usia antara 41-50 tahun berjumlah 17,65\%, dan $>50$ tahun berjumlah 3 orang atau $8,82 \%$.

Sehingga dapat disimpulkan bahwa responden dengan usia 31-40 tahun yang paling dominan dan usia > 50 tahun yang paling sedikit, hal ini dikarenakan pada usia 31-40 tahun merupakan usia produktif sehingga banyak perempuan dikisaran usia tersebut yang paling banyak berdagang dibandingkan dengan usia $>51$ tahun dimana usia ini merupakan usia non produktif sehingga lebih sedikit perempuan di usia ini yang berdagang di Pasar Sanggeng Manokwari.

\section{Distribusi Jam Kerja Responden Pedagang Perempuan}

Tinggi rendahnya jam kerja tidak selalu memberi pengaruh bagi pendapatan pedagang perempuan, namun yang mendasari tinggi rendahya pendapatan pedagang perempuan adalah pola yang tidak tetap dimana tergantung pada jenis usaha dan kecepatan waktu terjualnya barang dagangan (Simanjuntak, 1998).

Tabel 4. Distribusi Jam Kerja Responden Pedagang Perempuan

\begin{tabular}{crrrr}
\hline Waktu & \multicolumn{2}{c}{ Sektor Sekunder } & \multicolumn{2}{c}{ Sektor Primer } \\
\cline { 2 - 5 } Kerja /hari & Orang & \multicolumn{1}{c}{$\%$} & Orang & \% \\
\hline$<5$ & 3 & 6,12 & 3 & 8,82 \\
\hline $5-7$ & 10 & 20,41 & 6 & 17,65 \\
\hline $7-8$ & 12 & 24,49 & 8 & 23,53 \\
\hline$>8$ & 24 & 48,98 & 17 & 50,00 \\
\hline Total & 49 & 100 & 34 & 100 \\
\hline \multicolumn{2}{c}{ Total Responden } & & $\mathbf{8 3}$ & \\
\hline
\end{tabular}

Sumber: data primer diolah, 2019

Tabel 4 menunjukkan distribusi jam kerja responden pedagang perempuan berdasarkan jenis usaha yang dikelompokan menjadi dua sektor yaitu sektor sekunder yang meliputi jenis usaha warung makan, pakaian, sepatu dan pinang dan sektor primer yang meliputi jenis usaha sayur, dan hasil kebun menunjukkan bahwa responden dengan jam kerja $>8$ jam yang paling dominan dan responden dengan jam kerja $<5$ jam yang paling sedikit

\section{Distribusi Tingkat Pendidikan Responden Pedagang Perempuan}

Jenjang pendidikan yang dicapai seseorang akan menentukan posisi kerja seseorang. Dalam penelitian ini tingkat pendidikan dihitung dengan menghitung tahun terakhir pedagang perempuan menamatkan pendidikannya. Tingkat pendidikan responden bervariasi dari yang berpendidikan dasar hingga pendidikan tinggi.

Tabel 5. Distribusi Tingkat Pendidikan Responden Pedagang Perempuan

\begin{tabular}{|c|c|c|c|c|}
\hline \multirow{2}{*}{$\begin{array}{l}\text { Tingkat } \\
\text { Pendidikan }\end{array}$} & \multicolumn{2}{|c|}{ Sektor Sekunder } & \multicolumn{2}{|c|}{ Sektor Primer } \\
\hline & Orang & $\%$ & Orang & $\%$ \\
\hline 6 & 10 & 20,41 & 6 & 17,65 \\
\hline 9 & 13 & 26,53 & 10 & 29,41 \\
\hline 12 & 24 & 48,98 & 17 & 50,00 \\
\hline$>12$ & 2 & 4,08 & 1 & 2,94 \\
\hline Total & 49 & 100 & 34 & 100 \\
\hline \multicolumn{3}{|c|}{ Total Responden } & \multicolumn{2}{|c|}{83} \\
\hline
\end{tabular}

Sumber: data primer diolah, 2019

Dari Tabel 5 diketahui ditribusi tingkat pendidikan responden pedagang perempuan berdasarkan jenis usaha yang dikelompokan menjadi dua sektor yaitu sektor sekunder yang meliputi jenis usaha warung makan, pakaian, sepatu dan pinang dan sektor primer yang meliputi jenis usaha sayur, dan hasil kebun menunjukkan bahwa responden yang dominan ialah responden dengan tingkat pendidikan 12 tahun (SMA) dan yang paling sedikit ialah responden dengan tingkat pendidikan $>12$ tahun (S1/D3).

\section{Distribusi Jumlah Tanggungan Responden Pedagang Perempuan}

Tabel 6. Distribusi Jumlah Tanggungan Responden Pedagang Perempuan

\begin{tabular}{crrrr}
\hline Jumlah & \multicolumn{2}{c}{ Sektor Sekunder } & \multicolumn{2}{c}{ Sektor Primer } \\
\cline { 2 - 6 } Tanggungan & \multicolumn{1}{c}{ Orang } & \multicolumn{1}{c}{$\%$} & Orang & \multicolumn{1}{c}{$\%$} \\
\hline 1 & 2 & 4,08 & 1 & 2,94 \\
\hline 2 & 0 & 0 & 0 & 0 \\
\hline 3 & 10 & 20,41 & 6 & 17,65 \\
\hline 4 & 13 & 26,53 & 10 & 29,41 \\
\hline 5 & 24 & 48,98 & 17 & 50,00 \\
\hline Total & 49 & 100 & 34 & 100 \\
\hline \multicolumn{2}{c}{ Total Responden } & & $\mathbf{8 3}$ & \\
\hline
\end{tabular}

Sumber : data primer diolah, 2019

Jumlah tanggungan menjadi salah satu faktor perempuan bekerja dikarenakan jumlah tanggungan dalam keluaga yang banyak akan membuat perempuan bekerja untuk menutupi 
kebutuhan tanggungan yang ada dalam kelurga pedagang perempuan.

Dari tabel 6 diketahui responden dengan jumlah tanggungan berdasarkan jenis usaha yang dikelompokan menjadi dua sektor yaitu sektor sekunder dan primer menunjukkan bahwa responden dengan jumlah tanggungan 5 orang yang paling dominan dibandingkan responden dengan jumlah tanggungan 2 orang yang jumlah respondennya lebih sedikit.

\section{Distribusi Pendapatan Pedagang Perempuan}

Tabel 7. Distribusi Pendapatan Pedagang Perempuan

\begin{tabular}{crrrr}
\hline \multirow{2}{*}{$\begin{array}{c}\text { Pendapatan } \\
\text { (Juta Rp/Bln) }\end{array}$} & \multicolumn{2}{c}{$\begin{array}{c}\text { Sektor } \\
\text { Sekunder }\end{array}$} & \multicolumn{2}{c}{$\begin{array}{c}\text { Sektor } \\
\text { Primer }\end{array}$} \\
\cline { 2 - 5 } & Orang & \multicolumn{1}{c}{$\%$} & Orang & \multicolumn{1}{c}{$\%$} \\
\hline $8-11,5$ & 4 & 8,16 & 32 & 94,11 \\
\hline $12-14$ & 13 & 26,53 & 2 & 5,89 \\
\hline $14-19$ & 24 & 48,98 & 0 & 0 \\
\hline$>19$ & 8 & 16,32 & 0 & 0 \\
\hline Total & 49 & 100 & 34 & 100 \\
\hline \multicolumn{2}{c}{ Total Responden } & & $\mathbf{8 3}$ &
\end{tabular}

\section{Sumber : data primer diolah, 2019}

Pendapatan dari pedagang perempuan akan sangat membantu jika dibandingkan hanya mengandalkan pendapatan suami yang diidentikan sebagai tulang punggung keluarga menunjukkan bahwa responden dengan jumlah pendapatan 8-11,5 juta yang paling mendominasi dan responden dengan pendapatan $>19$ juta yang paling sedikit. Hasil analisis regresi linear berganda faktor umur, jam kerja, tingkat pendidikan, jumlah tanggungan yang mempengaruhi pendapatan pedagang perempuan.

Hasil Analisis faktor umur, jam kerja, tingkat pendidikan, jumlah tanggungan yang mempengaruhi pendapatan pedagang perempuan dapat dilihat pada tabel 8 .

Dari tabel di atas dapat ditulis dalam persamaan regresi linear berganda sebagai berikut:

$\mathrm{Y}=27,794+-0,183(\mathrm{X} 1)+-0,707(\mathrm{X} 2)+0,117$

$(\mathrm{X} 3)+-0,216(\mathrm{X} 4)+\mathrm{e}$

Keterangan:

$\mathrm{Y}=$ Pendapatan

$\mathrm{X} 1=$ Umur

$\mathrm{X} 2=$ Jam Kerja

$\mathrm{X} 3=$ Tingkat Pendidikan

$\mathrm{X} 4=$ Jumlah Tanggungan
Tabel 8. Hasil Regresi Linear Berganda (Coefficients*)

\begin{tabular}{llll}
\hline \multirow{2}{*}{ Model } & \multicolumn{2}{l}{$\begin{array}{l}\text { Unstandardized } \\
\text { Coefficients }\end{array}$} & $\begin{array}{l}\text { Standardi } \\
\text { Coefficien }\end{array}$ \\
\cline { 2 - 4 } & $\mathrm{B}$ & Std. Error & Beta \\
\hline (Constant) & 27.794 & 5.195 & \\
\hline Umur $\left(\mathbf{X}_{\mathbf{1}}\right)$ & -.183 & .071 & -.329 \\
\hline Jam Kerja $\left(\mathbf{X}_{\mathbf{2}}\right)$ & -.707 & .142 & -.629 \\
\hline Tingkat Pendidikan $\left(\mathbf{X}_{\mathbf{3}}\right)$ & .117 & .460 & .027 \\
\hline Jumlah Tanggungan $\left(\mathbf{X}_{\mathbf{4}}\right)$ & -.216 & .357 & -.060 \\
\hline Sumber : data primer diolah, 2019 & &
\end{tabular}

Koefisien Determinasi $\left(\mathrm{R}^{2}\right)$ digunakan untuk mengukur seberapa jauh kemampuan sebuah model menerangkan variasi variabel independen. Nilai koefisien determinasi adalah antara 0 dan 1 , jika nilai R2 kecil atau mendekatii angka nol (0) berarti kemampuan variabel-variabel independen dalam menjelaskan variabel dependen sangat terbatas, namun jika nilai yang mendekati 1 berarti variabel-variabel independen memberikan hampir semua informasi yang dibutuhkan untuk memprediksi variabel dependen, (Ghozali, 2006). Nilai R2 dalam penelitian yaitu sebesar 0,262 mendekati angka nol atau sebesar 26,2\% yang artinya variabel pendapatan pedagang perempuan (Y) hanya dapat dijelaskan oleh variabel-variabel independen yaitu umur (X1), jam kerja (X2), tingkat pendidikan (X3), dan jumlah tanggungan (X4), sebesar 26,2\% dan sisanya sebesar 73,8\% dijelaskan oleh variabel-variabel lain diluar empat variabel yang digunakan dalam penelitian ini atau variabel lain yang tidak digunakan dalam penelitian ini. Meskipun nilai R2 rendah, namun secara uji simultan atau uji $F$ menunjukan bahwa variabel Umur (X1), Jam Kerja (X2), Tingkat pendidikan (X3), dan Jumlah Tanggungan (X4) secara bersama-sama (simultan) mempengaruhi variabel pendapatan pedagang $(\mathrm{Y})$. hal ini ditunjukan dengan nilai signifikansi sebesar $0,000<0,05$ sehingga dapat disimpulkan bahwa Ho ditolak dan Ha diterima, yang artinya variabel Umur (X1), Jam Kerja (X2), Tingkat Pendidikan (X3), dan Jumlah Tanggungan (X4) secara bersama-sama (simultan) berpengaruh terhadap variabel pendapatan Pedagang Perempuan (Y).

\section{Uji F Statistik}

Uji F menunjukan apakah variabel independen atau bebas yang dimasukan dalam model mempunyai pengaruh secara bersama-sama terhadap variabel dependen atau terikat. Uji Simultan atau Uji F menunjukan bahwa variabel Umur (X1), Jam Kerja (X2), Tingkat pendidikan (X3), dan Jumlah Tanggungan (X4) secara bersama-sama (simultan) mempengaruhi variabel 
pendapatan pedagang $(\mathrm{Y})$. hal ini ditunjukan dengan nilai signifikansi sebesar $0.000<0.05$ sehingga dapat disimpulkan bahwa Ho ditolak dan Ha diterima, yang artinya variabel Umur
(X1), Jam Kerja (X2), Tingkat Pendidikan (X3), dan Jumlah Tanggungan (X4) secara bersamasama (simultan) berpengaruh terhadap variabel pendapatan Pedagang Perempuan (Y).

Tabel 9. Hasil Pengujian Secara Simultan

\begin{tabular}{|c|c|c|c|c|c|}
\hline $\begin{array}{l}\text { JOVA }^{\mathrm{b}} \\
\text { Model }\end{array}$ & Sum of Sauares & Df & Mean Square & & Sig \\
\hline Regression & 250.070 & 4 & 62.518 & 6.925 & $0.000^{\mathrm{a}}$ \\
\hline Residual & 704.219 & 78 & 9.028 & & \\
\hline Total & 954.289 & 82 & & & \\
\hline
\end{tabular}

\section{a. Predictors: (Constant), Jumlah Tanggungan (X4),
Kerja (X2) \\ b. Dependent Variable: Pendapatan Pedagang (Y) Sumber : data primer diolah, 2019}

\section{Uji Parsial (Uji T)}

Menurut Sugiyono (2015), Uji t pada dasarnya menunjukan seberapa jauh pengaruh suatu variabel penjelas secara parsial (secara individual) dalam menerangkan variasi variabel terikat. Tingkat kepercayaan atau tingkat resiko (level of significant) yang digunakan dalam pengujian ini adalah 95\% maka nilai (a) $=5 \%$ $(0,05)$.

Tabel 10. Hasil Pengujian Secara Parsial

\begin{tabular}{lll}
\hline Variabel Independen & T & Sig \\
\hline Umur $\left(\mathrm{X}_{1}\right)$ & -2.563 & .012 \\
\hline Jam Kerja $\left(\mathrm{X}_{2}\right)$ & -4.987 & .000 \\
\hline Tingkat Pendidikan $\left(\mathrm{X}_{3}\right)$ & 254 & .800 \\
\hline Jumlah Tanggungan $\left(\mathrm{X}_{4}\right)$ & -0.607 & .546 \\
\hline
\end{tabular}

1. Variabel Umur (X1) memiliki nilai signifikansi sebesar 0.012 nilai ini lebih kecil dari nilai alpha $0.05(0.012<0.05)$. sehingga dapat disimpulkan $\mathrm{HO}$ ditolak dan Ha diterima yang artinya variabel umur (X1) mempunyai pengaruh yang signifikan terhadap variabel pendapatan pedagang perempuan (Y) secara parsial.

2. Variabel Jam Kerja (X2) memiliki nilai signifikansi sebesar 0.000 nilai ini lebih kecil dari nilai alpha $0.05(0.00<0.05)$. sehingga dapat disimpulkan $\mathrm{H} 0$ ditolak dan $\mathrm{Ha}$ diterima yang artinya variabel jam kerja (X2) mempunyai pengaruh secara signifikan terhadap variabel pendapatan pedagang perempuan (Y) secara parsial.

3. Variabel Tingkat Pendidikan (X3) memiliki nilai signifikansi sebesar 0.800 nilai ini lebih besar dari nilai alpha $0.05(0.800>0.05)$. sehingga dapat disimpulkan $\mathrm{H0}$ diterima dan $\mathrm{Ha}$ ditolak yang artinya variabel tingkat pendidikan (X3) tidak mempunyai pengaruh signifikan terhadap variabel pendapatan pedagang perempuan $(\mathrm{Y})$ secara parsial.

4. Variabel Jumlah Tanggngan (X4) memiliki nilai signifikansi sebesar 0.546 nilai ini lebih besar dari nilai alpha $0.05(0.546>0.05)$. sehingga dapat disimpulkan Ho diterima dan Ha ditolak yang artinya variabel Jumlah Tanggungan (X4) tidak mempunyai pengaruh yang signifikan terhadap variabel pendapatan Pedagang Perempuan (Y) secara parsial.

\section{KESIMPULAN}

Berdasarkan hasil penelitian maka dapat disimpulkan sebagai berikut:

1. Pendapatan bersih pedagang perempuan di pasar sanggeng manokwari selama satu bulan bervariasi dari terendah Rp. 8.000.000 hingga tertinggi Rp. 20.00.000 dan rata-rata $\mathrm{Rp}$. 11.400.000

2. Faktor-faktor umur, jam kerja, tingkat pendidikan secara bersama-sama (simultan) berpengaruh signifikan terhadap pendapatan pedagang perempuan, Secara parsial faktorfaktor umur, dan jam kerja, berpengaruh signifikan dengan nilai negatif terhadap pendapatan pedagang perempuan di Pasar Sanggeng Manokwari, sedangkan untuk tingkat pendidikan, dan jumlah tanggungan tidak berpengaruh signifikan terhadap pendapatan pedagang perempuan di Pasar Sanggeng Manokwari. 


\section{DAFTAR PUSTAKA}

Atini, Ni Wayan Putu dan Handayani 2009. Kontribusi Pendapatan Ibu Rumah Tangga Pembuat Makanan Olahan Terhadap Pendapatan Keluarga. Piramida,5. 1:9-15

Badan Pusat Statistik Kabupaten Manokwari 2015. Manokwari Dalam Angka Tahun 2015. Manokwari : BPS.

Dewi, P. M. 2012. Partisipasi tenaga kerja perempuan dalam meningkatkan pendapatan keluarga. Jurnal Ekonomi Kuantitatif Terapan, 5(2), 44293.

Dinas Perindagkop Kabupaten Manokwari 2018. Data Jumlah Pedagang Perempuan di Pasar Sanggeng Manokwari.

Fitria, Majid., Herniwati Retno. 2012. FaktorFaktor Yang Mempengaruhi Keputusan Perempuan Berstatus Menikah Untuk Bekerja (Studi Kasus Kota Semarang) Jurusan IESP Fakultas Ekonomika dan Bisnis Universitas Diponegoro. Diponegoro Journal Of Economics, Vol 1, No 1 Tahun2012, hal 1 -9.

Fitriani, M. (2016). Pengaruh Wanita Bekerja, Tingkat Pendidikan Dan Jumlah Anggota Keluarga Terhadap Pendapatan Rumah Tangga Masyarakat Muslim Pada Kelurahan 20 Ilir Daerah Iv Kecamatan Ilir Timur I Kota Palembang.[SKRIPSI] (Doctoral dissertation, UIN RADEN FATAH PALEMBANG).

Ghozali, Imam, 2006, Aplikasi Analisis Multivariate dengan Program SPSS, Semarang, BP UNDIP.

Hardyastuti, Suhatmini., Hudayana, Bambang. 1991. Pekerja Perempuan Pada Industri Rumah Tangga Sandang diDaerah Istimewa Yogyakarta.Yogyakarta: Pusat Studi Kebijakan dan Kependudukan

Hasyim H. 2006. Analisis Hubungan Karakteristik Petani Kopi terhadap Pendapatan (Studi Kasus : Desa Dolok Saribu Kecamatan Paguran Tapanuli Utara). Jurnal Komunikasi Penelitian, 18,1:22-27

Pudjianto, Bambang dan Mukhlis 2006. Studi Kasus Wanita-Wanita Penambang Pasir di Desa Lumbung Rejo, Kecamatan
Tempel - Kabupaten Sleman. Jurnal Penelitian dan Pengembangan Kesejahteraan Sosial. 11.1: 15-24

Purnama, C., Yusnida, Y., \& Rambe, R. A. 2013. Analisis Faktor-Faktor yang Mempengaruhi Tingkat Partisispasi Wanita Bekerja Sektor Informal di Kota Bengkulu (Doctoral dissertation, Universitas Bengkulu).

Sari, Ida Ayu Dewi Purnama. 2010. Analisis Pengaruh Umur,Status Perkawinan dan Pendidikan Terhadap Pendapatan Pekerja Perempuan Sektor Informal Di Desa Tegal Jadi Kecamatan Marga Kabupaten Tabanan. Skripsi Sarjana Fakultas Ekonomi Universitas Udayana, Denpasar.

Simanjuntak, P.J. 1998. Pengantar Ekonomi Sumberdaya Manusia. Edisi Kedua. Jakarta: Lembaga Penerbit Fakultas Ekonomi Universitas Indonesia.

Sugiyono 2015, Metode Penelitian Bisnis, Penerbit Alfabet. Bandung.

Suhartini, S., 2010. Pergulatan Hidup Perempuan Pemecah Batu. KOMUNITAS: International Journal of Indonesian Society and Culture, 2(2).

Sumarsono, Sonny. 2003. Ekonomi Manajemen Sumber Daya Manusia dan Ketenaga kerjaan. Graha Ilmu. Jogyakarta.

Sunuharjo, Bambang. 2009. Kemiskinan dan Kebutuhan Pokok. Jakarta : Yayasan Ilmu Sosial.

Thasya, M., \& Muhammad, S. (2017). Pengaruh Pendidikan, Umur dan Curahan Jam Kerja Ibu Rumah Tangga Terhadap Pendapatan Keluarga (Studi Kasus: Ibu Rumah Tangga Yang Bekerja Di Industri Batu Bata Di Desa Kajhu Kecamatan Baitussalam). Jurnal Ilmiah Mahasiswa Ekonomi Pembangunan, 2(1), 105-115.

Undang-Undang Republik Indonesia (UU No.13/2003 Tentang Ketenagakerjaan). https://id.scridb.com/document/1331181 523/UU-no-13-2003-tentangketenagakerjaan 